\title{
THE EFFECT OF FOLIAR CALCIUM APPLICATION IN TOMATO (Solanum lycopersicum L.) UNDER DROUGHT STRESS IN GREENHOUSE CONDITIONS
}

\author{
BIRGIN, Ö. ${ }^{1}-$ AKHOUNDNEJAD, Y. $.^{*}-$ DASGAN, H. Y. ${ }^{2}$ \\ ${ }^{1}$ University of Sirnak, Faculty of Agriculture, Department of Horticulture, Sirnak, Turkey \\ ${ }^{2}$ University of Cukurova, Faculty of Agriculture, Department of Horticulture, Adana, Turkey \\ ${ }^{*}$ Corresponding author \\ e-mail: yakhoundnejad@sirnak.edu.tr; phone: +90-544-864-5435
}

(Received $14^{\text {th }}$ Jan 2021; accepted $14^{\text {th }}$ May 2021)

\begin{abstract}
Numerous studies have demonstrated the effects of drought stress on tomato yield. Significant role of mineralsin alleviating theadverse effects of abiotic stresses have been documented. Calcium is an essential mineral needed in plant growth and development and in serving as an intracellular messenger. However, alleviation of drought stress in tomato plants with the application of calcium has rarely been addressed. Therefore, this study was attempted to investigate the effects of foliar application of calcium sulphate $\left(\mathrm{CaSO}_{4}\right)$ on drought stress in tomato plants. The experiment was conducted in greenhouse conditions. Tomato plants were sprayed with $\mathrm{CaSO}_{4}$ solution and exposed to drought stress. The foliar application of $\mathrm{CaSO}_{4}$ increased magnesium and chlorophyll level. The results indicated that application of $\mathrm{CaSO}_{4}$ under drought conditions increased and regulated carbohydrate levels of leaves. Metabolite analysis revealed that a beneficial effect of $\mathrm{CaSO}_{4}$ on drought tolerance. The results indicated a promising result for foliar $\mathrm{CaSO}_{4}$ application providing improving mineral nutrition efficiency and therefore a higher tolerance to drought stress.Also, in drought stress, calcium application has been effective in yield significantly.
\end{abstract}

Keywords:tomato, $\mathrm{CaSO}_{4}$, yield, micro and macro nutrient, drought stress

\section{Introduction}

Tomato (Solanum lycopersicum L.) belongs to the Solanaceae family, which is one of the most widely cultivated and economically important vegetables in the world, containing about 2800 species (Lahoz et al., 2016). The tomato, native to Peru, is an annual vegetable and introduced to Turkey in 1900s. Tomato is a warm season crop; thus, requires a warm and mild climate (Gebhardt and Thomas, 2002). Total tomato production of Turkey in 2017 was 12750000 tons on an area of 187070 ha and ranked the third highest tomatoe producer in the world (FAO, 2017).

Nutritional value of tomatoe is quite high due to high vitamins A, B and C, calcium and carotene contents (Bose and Som, 1990). Gebhardt and Thomas (2002) indicated that a medium-size (123 g) tomato contains about 94\% water, $26 \mathrm{kcal}$ energy, $1 \mathrm{~g}$ protein, $6 \mathrm{~g}$ carbohydrate, $1.4 \mathrm{~g}$ total fiber, $6 \mathrm{mg} \mathrm{Ca}, 0.6 \mathrm{mg} \mathrm{Fe}, 273 \mathrm{mg} \mathrm{K}, 11 \mathrm{mg} \mathrm{Na}$, $766 \mathrm{IU}$ vitamin A, $0.07 \mathrm{mg}$ thiamine, $0.06 \mathrm{mg}$ riboflavin, $0.8 \mathrm{mg}$ niacin and $23 \mathrm{mg}$ ascorbic acid.Tomato is known as an ideal fleshy fruit model system due to unique characteristics such as easy grown under different conditions, short life span and simple genetics (Bergougnoux, 2014).

Drought is a major abiotic stress factor causing significant yield losses and quality of products (Bray, 2004; Wang and Frei, 2011; Trenberth et al., 2014). Irregularrainfall distribution patterns and excessive use of water resources to meet the demands of growing population increased the frequency and severity of drought events in many 
regions of the world (Bacon, 2004; Lee, 2007). Drought stress reduces transport of nutrients in tomatoe plants (Bauer et al., 1997) and nutrient uptake of roots (Naeem et al., 2017). Calcium (Ca), a macronutrient, is quite immobile in plants and Ca uptake of roots in drought conditions is adversely affected by limited access to water (Adams and Ho, 1993;Naeem et al., 2017). Calcium has a vital role for normal growth and development of plants due to an important role in balancing membrane structures, increasing nutrient uptakes and activates of metabolic processes (Tuna et al., 2007; Sarwat et al., 2013). In addition, the Ca is needed to maintain cell wall integrity and to ensure bindings between cells (Marschner, 1995). Calcium also reduces detrimental effects of stress by regulating antioxidant metabolism (Zorrig et al., 2012; Ahmad et al., 2015). Therefore, the Ca deficiency may cause reduction in fruit quality as well as blossom-end rot and many other physiological disorders (Adams and Ho, 1993). However, Ca requirement of plants must be met continuously to sustain healthy leaf and root development (Del-Amor and Marcelis, 2003). Foliar application of fertilizer is the most effective way to improve the nutritional status of plants (Shabbir et al., 2015). The aim of this greenhouse study was to investigate the effects of foliar calcium sulphate $\left(\mathrm{CaSO}_{4}\right)$ application on yield and quality of tomato under drought stress.

\section{Materials and Methods}

The study was carried out under farmer conditions in Birlik village of Silopi town at Sirnak province in Turkey. The experiment was conducted in a $3000 \mathrm{~m}^{2}$ greenhouse for 4-month of tomatoe production season and tomatoeplants were grown in soil. The seedlings of Aziz F1 tomato variety were planted on March 3, 2020 (Figure 1). The experiment had 4 treatments, 20 plants per repetition, which were $100 \%$ irrigation (control), 50\% irrigation, 50\%+calcium $1 \%$ and control+calcium $1 \%$. The temperature and the average humidity values of the greenhouse were recorded throughout the experiment.
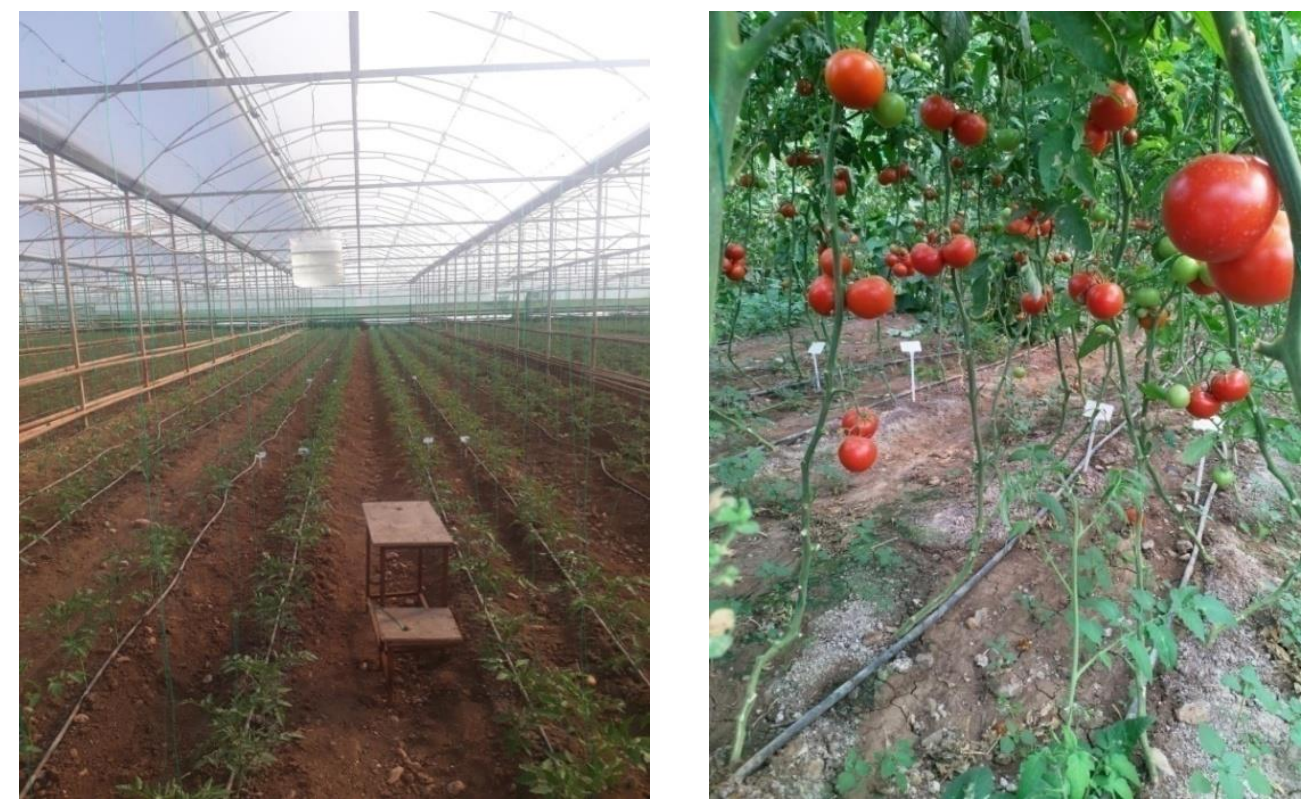

Figure 1. A view from the experiment 
The drought stress was applied modifying the method given in Akhoundnejad and Dasgan (2019). The amount of water used during the experiment was given in Table 1.Calcium sulphate $\left(\mathrm{CaSO}_{4}\right)$ was used as the source of $\mathrm{Ca}$ and $1 \%$ application dose was sprayed on leaves using a $16 \mathrm{~L}$ backpack pump. Spraying was carried out on April 10, 40 days after planting, and application was repeated every 20 days. The drought stress in tomatoe plants was created 30 days after planting the seedlings. Interrow and intrarow distances of tomato seedlings were 100 and $25 \mathrm{~cm}$, respectively. Fertilizer application rate in all treatments was $110 \mathrm{~kg} \mathrm{ha}^{-1} \mathrm{~N}, 190 \mathrm{~kg} \mathrm{ha}^{-1} \mathrm{~K}_{2} \mathrm{O}, 20 \mathrm{~kg} \mathrm{ha}^{-1} \mathrm{MgO}$ and $30 \mathrm{~kg} \mathrm{ha}^{-1} \mathrm{CaO}$.

Table 1. The amount of water used during experiment (plant $L^{-1}$ )

\begin{tabular}{c|c|c|c}
\hline Treatment & Water before stress $(\mathbf{L}) *$ & Water after stress $(\mathbf{L}) * *$ & Total water $(\mathbf{L})$ \\
\hline Control (100\%) & 21 & 79.80 & 100.8 \\
Drought stress (50\%) & 21 & 39.9 & 60.9 \\
\hline
\end{tabular}

* Before Stress (March 03-April 08, 2020), ** After Stress (April 14 - June 21, 2020)

\section{Tomato yield and yield components}

Tomato fruits were harvested from May to June. The weights for each replication were recorded to determine thetotal fruit yield $\left(\mathrm{kg} \mathrm{plant}^{-1}\right.$ and $\left.\mathrm{kg} \mathrm{m}^{-2}\right)$ for each treatment. The weights of tomato fruits from different replications were averaged to determine the average fruit weight of tomato fruits $\left(\mathrm{g} \mathrm{fruit}^{-1}\right)$. The number of tomato fruits in different replications was recorded and averaged to determine average number of fruits per plant (number plant ${ }^{-1}$ ).

Fruit juice was extracted from one slice of 5 fruits selected from each replication. The percentage of soluble dry matter in extracted juice was read using a refractometer (PCE-4582). Flesh firmness $(\mathrm{kg})$ of tomatoe fruits was determined using with a fruit penetrometer(GY-1). Five fruits were selected from each replication in the flesh firmness measurements.

The amount of water given to plants was recorded throughout the experiment. Water use efficiency was calculated by the ratio of total fruit yield to the total amount of water used. Water use efficiency indicates the efficient use of water in tomato production Akhoundnejad and Dasgan (2019) and calculated by the following Equation 1;

$$
W U F=\frac{Y}{A W}
$$

where, WUF is the water use efficiency; $\mathrm{Y}$ is the yield $\left(\mathrm{g} \mathrm{plant}^{-1}\right)$, and AW is the amount of applied water $\left(\mathrm{L} \mathrm{plant}^{-1}\right)$.

Chlorophyll content of tomato plants was measured using a SPAD meter (Minolta $502)$ in the morning hours when the sky was clear. Leaf temperatures $\left({ }^{\circ} \mathrm{C}\right)$ of tomato plants were measured from the $4^{\text {th }}$ leaves of plants using a Testo brand 104-IR model infrared thermometer between 09.00-10.00 am of the day. The measurements were carried out during the third harvest of the experiment.

Leaf samples were collected from 4-6 leaves down to the growth end in the $45^{\text {th }}$ day of the experiment. Leaf samples were washed with deionized water and dried in an oven at $60^{\circ} \mathrm{C}$. The dried and ground leaf samples were burned at $550^{\circ} \mathrm{C}$ for $6-7$ hours. The 
ashes were filtered by dissolving in $3.3 \%(\mathrm{v} / \mathrm{v}) \mathrm{HCl}$ acid. Nitrogen $(\mathrm{N})$, potassium $(\mathrm{K})$, magnesium $(\mathrm{Mg})$, calcium $(\mathrm{Ca})$, iron $(\mathrm{Fe})$, manganese $(\mathrm{Mn})$, copper $(\mathrm{Cu})$ and zinc $(\mathrm{Zn})$ contents of leaf samples were determined. Potassium, $\mathrm{Ca}, \mathrm{Mg}$ and $\mathrm{Na}$ contents were determined in emission mode, and $\mathrm{Fe}, \mathrm{Mn}, \mathrm{Zn}$ and $\mathrm{Cu}$ contents were in absorbance mode of an atomic absorption spectrometer. Nitrogen content of leaves were determined by wet combustion according to the Khjeldal method.Macro and micro element analysis was performed on Atomic Absorption Spectrophotometer device and FS220 model.

FolinCiocaltaeu method was used to determine total phenolic content $\left(\mathrm{mg} \mathrm{g}^{-1}\right)$ of tomato leaves (Singleton and Rossi, 1965). For phenolic content, $2 \mathrm{~g}$ of dried and ground leaf sample was weighed and $5 \mathrm{ml}$ methanol $75 \%$ (containing $0.1 \%$ formic acid) was added. Homogenization process was carried out with Ultra Turrax at $6000 \mathrm{rpm}$ in an ultrasonic water bath $\left(25^{\circ} \mathrm{C}, 10 \mathrm{~min}\right.$.). The mixture was centrifuged at $2500 \mathrm{rpm}$ for $10 \mathrm{~min}$ at room temperature and supernatant was poured into a clean tube. Extraction process was repeated twice, and final volume was adjusted to $10 \mathrm{ml}$ with methanol. The extract was diluted by adding $900 \mathrm{ml}$ of distilled water, then $5 \mathrm{ml}$ FCR $(0.2 \mathrm{M})$ was added and shaken vigorously. After standing 8 minutes, $5 \mathrm{ml}$ sodium carbonate $(7.5 \%)$ was added and mixed on a 20s vortex. The mixture was kept in dark for 2 hours at room temperature and absorbance was read at $765 \mathrm{~nm}$ by a spectrophotometer. The result was presented as $\mathrm{mg}$ gallic acid/g sample. Total flavonoids were determined using the method specified by Molina-Quijada et al. (2010). $1 \mathrm{ml}$ of extract was mixed with $4 \mathrm{ml}$ of deionized water and $0.3 \mathrm{ml}$ of $5 \% \mathrm{NaNO}_{2}$. Five minutes later, $0.3 \mathrm{ml}$ of $10 \% \mathrm{AlCl}_{3}, 2$ $\mathrm{ml}$ of $1 \mathrm{M} \mathrm{NaOH}$ and $10 \mathrm{ml}$ of deionized water were added. Absorbances of mixtures were read at $415 \mathrm{~nm}$ using a spectrophotometer.

Chlorophyll is one of the most important pigments providing coloring in plants and enables photosynthesis to take place. Green plants synthesize organic compounds using chlorophyll and light energy. Chlorophyll concentration $\left(\mathrm{mg} \mathrm{g}^{-1}\right)$ was determined according to Arnon (1949). In chlorophyll analysis, 100-200 mg of dried leaf samples were weighed, $10 \mathrm{ml}$ acetone (80\%) was added and homogenized. The absorbance values were read using a UV spectrophotometer at $663 \mathrm{~nm}, 652 \mathrm{~nm}, 645 \mathrm{~nm}$ and 470 $\mathrm{nm}$, respectively. Chlorophyll contents were calculated using the following equations (Equations 2,3, and 4).

$$
\begin{aligned}
& \text { Chlorophyll } \mathrm{a}=(12.7 \times A 663-2.7 \times A 645) \times\left(\frac{v}{1000 \times w}\right) \\
& \text { Chlorophyll } \mathrm{b}=(22.9 \times A 645-4.68 \times A 663) \times\left(\frac{v}{1000 \times w}\right) \\
& \text { Total chlorophyll }=(27.8 \times A 652) \times\left(\frac{v}{1000 \times w}\right)
\end{aligned}
$$

\section{Statistical analysis}

The effects of $\mathrm{Ca}$ and stress treatments on yield and plant characteristics were evaluated using JMP 13 statistical software. One-way ANOVA was used to test the differences in yield and plant characteristics between the treatments. The least significant difference test (LSD) at $95 \%$ probability was used to separate the means where ANOVA indicated significant differences. 


\section{Results and Discussion}

\section{Fruit weight (gnumber-1)and total fruit yield $\left(\mathrm{kg} \mathrm{ha}^{-1}\right)$}

Fruits, reached harvest maturity, were collected and the weights were weighed and recorded throughout the experiment. The mean weights of 5 tomato fruits at harvest maturity for each treatment were presented in Table 2. The difference in mean fruit weights between the treatments was not statistically significant. The highest mean fruit weight $\left(167.14 \mathrm{~g}\right.$ piece $\left.^{-1}\right)$ was recorded in control, while the lowest value $\left(152.85 \mathrm{~g} \mathrm{piece}^{-1}\right)$ was in $50 \%$ irrigation application. The fruit weights for each treatment were summed to determine the total yield $\left(\mathrm{kg} \mathrm{ha}^{-1}\right)$ for each treatment (Table $2)$. The effects of treatments on total tomato yield was statistically significant $(\mathrm{p}<0.05)$. The highest total yield $\left(7830 \mathrm{~kg} \mathrm{ha}^{-1}\right)$ was obtained in control and Catreatment $(7790 \mathrm{~kg}$ $\left.\mathrm{ha}^{-1}\right)$, while the lowest value was recorded in $50 \%$ irrigation treatment $\left(4710 \mathrm{~kg} \mathrm{ha}^{-1}\right)$. Total fruit yield in 50\% irrigation $+\mathrm{Ca}$ treatment was higher compared to the yield in $50 \%$ irrigation treatment. Daldal (2018) investigated the effects of different $\mathrm{CaSO}_{4}$ doses $\left(0,100,200,300 \mathrm{~g} \mathrm{Ca} \mathrm{m}^{-2}\right)$ on fruit yield and quality of tomato, and reported that $100 \mathrm{~g} \mathrm{Ca} \mathrm{m}^{-2}$ doseincreased the diameter and size of tomato fruits. Tanveer et al. (2020) investigated the effects 5 and $10 \mathrm{mM} \mathrm{Ca}$ concentrations on germination and growth parameters of tomato and indicated that $\mathrm{Ca}$ application increased the growth of tomato seedlings.

Table 2. Total fruit yield $\left(\mathrm{kg} \mathrm{ha}^{-1}\right)$, number of fruits (number plant $\left.{ }^{-1}\right)$, mean fruit weight $\left(\mathrm{g}\right.$ piec $\left.\mathrm{e}^{-1}\right)$, chlorophyll content, Brix, relative water content $(R W C)$ andleaf temperature $\left({ }^{\circ} \mathrm{C}\right)$ values for different treatments

\begin{tabular}{c|c|c|c|c|c|c|c}
\hline Treatments & $\begin{array}{c}\text { Total } \\
\text { Fruit } \\
\text { Yield } \\
\left(\text { kg ha }^{-1}\right)\end{array}$ & $\begin{array}{c}\text { Number } \\
\text { of fruits } \\
(\mathbf{f r u i t} \\
\left.\text { plant }^{-1}\right)\end{array}$ & $\begin{array}{c}\text { Average } \\
\text { fruit } \\
\text { weight } \\
\left(\mathbf{g}_{\text {piece }}^{-1}\right)\end{array}$ & Brix & $\begin{array}{c}\text { RWC } \\
(\%)\end{array}$ & $\begin{array}{c}\text { Leaf } \\
\text { Temperature } \\
\left({ }^{\circ} \mathbf{C}\right)\end{array}$ & Chlorophyll \\
\hline Control & $7830 \mathrm{a}$ & $46.80 \mathrm{a}$ & $167.14 \mathrm{a}$ & $4.57 \mathrm{a}$ & $61.95 \mathrm{a}$ & $31.60 \mathrm{c}$ & $45.63 \mathrm{~b}$ \\
Calcium & $7790 \mathrm{a}$ & $47.27 \mathrm{a}$ & $159.01 \mathrm{a}$ & $4.63 \mathrm{a}$ & $72.66 \mathrm{a}$ & $33.43 \mathrm{bc}$ & $53.93 \mathrm{a}$ \\
$50 \%$ Irrigation + Calcium & $6410 \mathrm{~b}$ & $34.80 \mathrm{~b}$ & $156.58 \mathrm{a}$ & $4.67 \mathrm{a}$ & $66.78 \mathrm{a}$ & $35.60 \mathrm{a}$ & $45.80 \mathrm{~b}$ \\
50\% Irrigation & $4710 \mathrm{c}$ & $44.00 \mathrm{a}$ & $152.85 \mathrm{a}$ & $5.43 \mathrm{a}$ & $64.13 \mathrm{a}$ & $34.73 \mathrm{ab}$ & $47.67 \mathrm{ba}$ \\
\hline LSD $_{0.05}$ & 0.91 & 4.45 & 34.79 & 0.96 & 13.57 & 2.07 & 6.27 \\
\hline $\mathrm{p}$ & $*$ & $* *$ & $\mathrm{~ns}$ & $\mathrm{~ns}$ & $\mathrm{~ns}$ & $0.0146^{*}$ & $\mathrm{~ns}$ \\
\hline
\end{tabular}

* Important at $\mathrm{p} \leq 0.05 * *$ Important at $\mathrm{p} \leq 0.01, \mathrm{~ns}=$ not significantly

\section{Number of fruits (fruit plant ${ }^{-1}$ )}

The mean number of fruits for each treatment collected from the first to last harvest was given in Table 2. The effects of treatments on the number of fruits per plant was significant $(\mathrm{p}<0.05)$. The highest number of fruits $(47.27)$ was recorded in $\mathrm{Ca}$ application, while the lowest number of fruits (34.80) was obtained in 50\% irrigation + Ca treatment (Table 2).

\section{Leaf chlorophyll content (SPAD)}

Mean chlorophyll contents recorded in different treatments were given in Table 2. The chlorophyll content recorded under different treatments was not statistically different. The highest mean chlorophyll content (53.93) was obtained in Ca application, while the lowest mean value was recorded in control (45.63). Although the difference in 
chlorophyll content between control and the treatments was not significant, $\mathrm{Ca}$ application may be a useful strategy to increase drought tolerance of tomato plants and prevent yield losses. The leaf chlorophyll contents recorded were similar to those reported by Mishra et al. (2012) and Sadak (2018) who investigated the effects of drought stress on tomato and pepper seedlings.

\section{Water soluble dry matter content (Brix \%)}

Water soluble dry matter content (Brix \%) of fruit juice that determined using a hand refractometer were given in Table 2. The difference in Brix values between the treatments was not statistically different. The highest Brix value $(5.43 \%)$ was recorded in \%50 irrigation application and the lowest value was obtained in control (4.57\%). The results revealed that water soluble dry matter content of fruit juice increased with the increase drought stress.

\section{Relative water content of leaves}

Relative water content (RWC) of leaves under different treatments were given in Table 2. The difference in RWC values between the treatments was not statistically significant. The highest RWC value $(72.66 \%)$ was obtained in Ca application, while the lowest value $(61.95 \%)$ was detected in control. The mean RWC in $50 \%$ irrigation $+\mathrm{Ca}$ treatment was higher than that recorded in 50\% irrigation application. Similarly, Kabay and Şensoy (2016) reported lower RWC values for bean genotypes grown under drought stress compared to control treatment.

\section{Leaf temperature}

Leaf temperatures $\left({ }^{\circ} \mathrm{C}\right)$ that recorded during the third harvest period were given in Table 2. The effects of treatments on leaf temperature was statistically significant $(\mathrm{p}<0.05)$. The highest leaf temperature $\left(35.60^{\circ} \mathrm{C}\right)$ value was recorded in $50 \%$ irrigation + Ca application, while the lowest temperature value $\left(31.60^{\circ} \mathrm{C}\right)$ was obtained in control application. The results showed that leaf temperatures of plants under drought stress increased as the stomata closure.

\section{Macro (\%) and micro (mg $\left.\mathrm{kg}^{-1}\right)$ nutrient contents of leaves and fruits (mg 100g $\mathrm{g}^{-1}$ )}

The highest leaf $\mathrm{K}$ content $(9.51 \%)$ was obtained in control and the lowest $(4.31 \%)$ in $\mathrm{Ca}$ application. The occurrence of lowest $\mathrm{K}$ content under $\mathrm{Ca}$ application might be attributed to the antagonism between $\mathrm{Ca}$ and $\mathrm{K}$. Potassium content under $50 \%$ irrigation treatment was $6.34 \%$ (Table 3). The highest fruit $\mathrm{K}$ content $\left(130.96 \mathrm{mg}^{100 \mathrm{~g}^{-1}}\right.$ ) was recorded in control, while the lowest content was obtained in 50\% irrigation $\left(90.74 \mathrm{mg}_{\left.100 \mathrm{~g}^{-1}\right)}\right.$ treatment (Table 4). Potassium is the most important nutrient to alleviate the effects of stress. Potassium is an extremely important mineral nutrient for marketing of fruit, quality parameters and human health (Lester et al., 2010). In addition, $\mathrm{K}$ plays an important role in vitamin $\mathrm{C}$ storage and pigment formation in fruits (lycopene and beta-carotene) (Ramiérez et al., 2012).

The highest leaf $\mathrm{Ca}$ content $(9.70 \%)$ was obtained in $\mathrm{Ca}$ application, while the lowest $\mathrm{Ca}$ content $(7.43 \%)$ was obtained in $50 \%$ irrigation treatment. Mean Ca content of tomato leaves in control treatment was $8.73 \%$ (Table 3). The highest $\left(55.37 \mathrm{mg}^{\left.100 \mathrm{~g}^{-1}\right)}\right.$ and the lowest fruit $\mathrm{Ca}\left(40.21 \mathrm{mg} 100 \mathrm{~g} \mathrm{~g}^{-1}\right)$ contents were determined in $50 \%$ irrigation treatment (Table 4). Membrane damage occurs when cells exposure to temperatures 
below optimum levels. Calcium increases heat tolerance of membrane (Starck et al., 1995). Therefore, sufficient $\mathrm{Ca}$ content in individual organs prevent the incidence and severity of physiological disorders cause by adverse external conditions (Poovaiah, 1993; Starck et al., 1995).

Table 3. Macro (\%) and micronutrient $\left(\mathrm{mg} \mathrm{kg}^{-1}\right)$ contents of leaves under drought stress and calcium application

\begin{tabular}{c|c|c|c|c|c|c|c|c|c}
\hline Application & Ca & K & Mg & N & Cu & Fe & Mn & Zn \\
\hline & \multicolumn{9}{|c}{$\%$} \\
\hline Control & $8.73 \mathrm{~b}$ & $9.51 \mathrm{a}$ & $0.88 \mathrm{~b}$ & $4.44 \mathrm{a}$ & $3.63 \mathrm{a}$ & $93.00 \mathrm{c}$ & $145 \mathrm{bc}$ & $24.33 \mathrm{a}$ \\
Calcium & $9.70 \mathrm{a}$ & $4.31 \mathrm{c}$ & $0.81 \mathrm{c}$ & $4.49 \mathrm{a}$ & $3.47 \mathrm{a}$ & $98.00 \mathrm{~b}$ & $143 \mathrm{c}$ & $23.00 \mathrm{~b}$ \\
$50 \%$ Irrigation + Calcium & $8.32 \mathrm{c}$ & $7.40 \mathrm{~b}$ & $0.94 \mathrm{a}$ & $3.41 \mathrm{~b}$ & $3.19 \mathrm{a}$ & $112.3 \mathrm{a}$ & $168 \mathrm{a}$ & $18.00 \mathrm{c}$ \\
$50 \%$ Irrigation & $7.43 \mathrm{~d}$ & $6.38 \mathrm{~b}$ & $0.71 \mathrm{c}$ & $3.11 \mathrm{~b}$ & $2.1 \mathrm{~b}$ & $73.00 \mathrm{~d}$ & $152 \mathrm{~b}$ & $16.00 \mathrm{~d}$ \\
\hline LSD $_{0.05}$ & 0.26 & 0.04 & 0.02 & 0.28 & 0.51 & 1.99 & 8.88 & 0.57 \\
\hline $\mathrm{p}$ & $* *$ & $* *$ & $* *$ & $* *$ & $* *$ & $* *$ & $* *$ & $* *$ \\
\hline
\end{tabular}

* Important at $\mathrm{p} \leq 0.05, * *$ Important at $\mathrm{p} \leq 0.01$

Table 4. Macro and micronutrient ( $\mathrm{mg} 100 \mathrm{~g}^{-1}$ dry weight) contents in tomato fruits under drought stress and Ca applications

\begin{tabular}{c|c|c|c|c|c|c|c|c}
\hline Treatments & $\mathbf{C a}$ & $\mathbf{K}$ & $\mathbf{M g}$ & $\mathbf{N}$ & $\mathbf{C u}$ & $\mathbf{F e}$ & $\mathbf{M n}$ & $\mathbf{Z n}$ \\
\hline Control & $41.22 \mathrm{~b}$ & $130.96 \mathrm{a}$ & $16.27 \mathrm{ab}$ & $4.70 \mathrm{c}$ & $2.00 \mathrm{a}$ & $15.17 \mathrm{a}$ & $5.51 \mathrm{~b}$ & $12.33 \mathrm{a}$ \\
Calcium & $55.37 \mathrm{a}$ & $122.96 \mathrm{a}$ & $8.21 \mathrm{c}$ & $6.23 \mathrm{a}$ & $2.23 \mathrm{a}$ & $12.23 \mathrm{~b}$ & $4.59 \mathrm{c}$ & $11.00 \mathrm{~b}$ \\
$50 \%$ Irrigation +Calcium & $40.22 \mathrm{~b}$ & $110.96 \mathrm{a}$ & $11.22 \mathrm{bc}$ & $5.79 \mathrm{~b}$ & $1.50 \mathrm{~b}$ & $11.31 \mathrm{c}$ & $4.36 \mathrm{~d}$ & $16.66 \mathrm{c}$ \\
$50 \%$ Irrigation & $40.21 \mathrm{~b}$ & $90.74 \mathrm{~b}$ & $19.30 \mathrm{a}$ & $3.46 \mathrm{~d}$ & $1.23 \mathrm{~b}$ & $9.20 \mathrm{~d}$ & $6.32 \mathrm{a}$ & $17.33 \mathrm{c}$ \\
\hline LSD $_{0.05}$ & 0.022 & 0.082 & 0.048 & 0.19 & 0.26 & 0.28 & 0.17 & 1.09 \\
\hline $\mathrm{p}$ & $*$ & $*$ & $*$ & $* *$ & $* *$ & $* *$ & $* *$ & $* *$ \\
\hline
\end{tabular}

* Important at $\mathrm{p} \leq 0.05 * *$ Important at $\mathrm{p} \leq 0.01$

The effect of treatments on $\mathrm{Mg}$ content tomato leaves was statistically significant. The highest $\mathrm{Mg}$ content $(0.94 \%)$ was obtained in $50 \%$ irrigation + Ca treatment, while the lowest $\mathrm{Ca}$ content $(0.71 \%)$ was in $50 \%$ irrigation treatment. Mean $\mathrm{Mg}$ content of tomato leaves in control treatment was $0.88 \%$ (Table 3). The highest fruit $\mathrm{Mg}$ content $\left(19.30 \mathrm{mg} 100 \mathrm{~g}^{-1}\right)$ was recorded in $50 \%$ irrigation, while the lowest $\mathrm{Mg}$ content (8.21 mg $100 \mathrm{~g} \mathrm{~g}^{-1}$ ) obtained in Ca application (Table 4). Calcium plays a beneficial role under drought stress in tomato plants. The drought stress and $\mathrm{Ca}$ application increased the synthesis of higher $\mathrm{Mg}$ soluble sugars that positively increased the chlorophyll level in leaves.

The highest leaf and fruit nitrogen contents $\left(4.44 \%\right.$ and $\left.6.23 \mathrm{mg} 100 \mathrm{~g}^{-1}\right)$ were obtained in $\mathrm{Ca}$ application and the lowest values $\left(3.9 \%\right.$ and $3.46 \mathrm{mg} 100 \mathrm{~g}^{-1}$ ) were recorded in 50\% drought stress (Tables 3 and 4). Photosynthesis of green plants decreases under stress conditions, therefore, nitrogen content also decreases accordingly. Wahocho et al. (2017) investigated the effects of various nitrogen applications on the economic performance of muskmelon, and indicated that a positive effect high $\mathrm{N}$ fertilizer application on vegetative traits such as tallest plants with more branches. The researchers also showed significant effects of high $\mathrm{N}$ application on fruits characteristics and fruit yield. In our study, $\mathrm{N}$ fertilizer proved to have a significant positive effect on the initial growth of tomato seedlings. 
Micronutrient contents of tomato leaves significant $(\mathrm{p}<0.05)$ changed with the application of $\mathrm{Ca}$ and drought stress. Leaf Fe content in the control was $93 \mathrm{mg} \mathrm{kg}^{-1}$. The highest leaf $\mathrm{Fe}$ content $\left(112 \mathrm{mg} \mathrm{kg}^{-1}\right)$ was obtained in $\mathrm{Ca}+50 \%$ irrigation treatment, while the lowest Fe content $(73 \mathrm{ppm})$ was recorded in $50 \%$ irrigation treatment. The highest leaf $\mathrm{Mn}$ content $\left(168 \mathrm{mg} \mathrm{kg}^{-1}\right)$ was obtained in 50\% irrigation + Ca application, while the lowest Mn content was in Ca application $\left(152 \mathrm{mg} \mathrm{kg}^{-1}\right)$. Mean $\mathrm{Zn}$ content of leaves in control was $24.33 \mathrm{mg} \mathrm{kg}^{-1}$, which is sufficient for healthy plant growth. The lowest leaf $\mathrm{Zn}$ content ( $16 \mathrm{mg} \mathrm{kg}^{-1}$ ) was obtained in $50 \%$ irrigation (Table 3). Mean $\mathrm{Zn}$ content of tomato fruits in $50 \%$ irrigation + Ca treatment was $16.66 \mathrm{mg} 100 \mathrm{~g} \mathrm{~g}^{-1}$, while $\mathrm{Zn}$ content of fruits under $\mathrm{Ca}$ application was $11.00 \mathrm{mg} 100 \mathrm{~g}^{-1}$. The highest and the

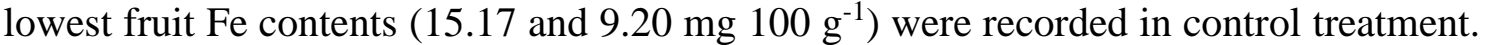
The highest fruit Mn content $\left(6.32 \mathrm{mg} 100 \mathrm{~g} \mathrm{~g}^{-1}\right)$ was obtained in $50 \%$ irrigation treatment and the lowest fruit $\mathrm{Mn}$ content $\left(4.36 \mathrm{mg} 100 \mathrm{~g}^{-1}\right.$ ) was in $50 \%$ irrigation $+\mathrm{Ca}$ application (Table 4). The results revealed that stress treatments caused a significant decrease in micronutrient contents of leaves and fruits.

In addition, the effect of stress in plants can be prevented with the application of Ca. Bjelić et al. (2005) reported that $\mathrm{Cu}$ content of tomato plants in greenhouse and open field is quite stable under various environmental conditions (high and low temperature and humidity, early or late harvest time etc.). Iron is the most abundant micro element in plants. In addition, $\mathrm{Fe}$ has a significant influence on quality of tomatoe fruits due to an important role in metabolic processes. Iron is also very active in many enzymatic systems such as photosynthesis, respiration and chlorophyll synthesis in plants (Houimli et al., 2017). Inactivity or slow transfer in plant is characteristic for $\mathrm{Fe}$, and $\mathrm{Fe}$, therefore, usually remains in roots and young leaves. Inactivity or slow transfer characteristic of Fe causes low and unstable Fe content in tomato plants (Bjelić et al., 2005).

\section{Total phenolic and flavonoid compounds ( $\mathrm{mg} \mathrm{g}^{-1}$ )}

The effects treatments on total phenolic and flavonoid compounds was statistically significant $(\mathrm{p}<0.01)$. The lowest mean total phenolic and flavonoid compounds $(9.59$ and $69.42 \mathrm{mg} \mathrm{g}^{-1}$ ) were recorded in Ca application, while the highest values (12.60 and $96.17 \mathrm{mg} \mathrm{g}^{-1}$ ) were recorded in 50 irrigation treatment (Table 5). Phenolic compounds, commonly found in plants, are secondary metabolism products and are involved in ecological and physiological events (Okunlola et al., 2017). One of the most important properties of phenolic compounds in plants is their antioxidant activity. Reactive oxygen species are formed in the cells due to metabolic events. The antioxidant activity of phenolic compounds can be attributed to the fact that free radicals formed by oxidation are extinguished by releasing hydrogen (Es-Safi et al., 2007). Phenolic compounds inhibit lipid peroxidation by trapping lipid alkyl radicals (Michalak, 2006).

Table 5. Flavonoid, total phenolic and chlorophyll contents of tomato plants $\left(\mathrm{mg}^{-1}\right)$

\begin{tabular}{c|c|c|c|c|c}
\hline Treatments & Total Flavonoid & Total phenolic & $\begin{array}{c}\text { Chlorophyll } \\
\mathbf{a}\end{array}$ & $\begin{array}{c}\text { Chlorophyll } \\
\mathbf{b}\end{array}$ & $\begin{array}{c}\text { Chlorophyll } \\
\mathbf{a ~ b}\end{array}$ \\
\hline Control & $73.87 \mathrm{c}$ & $10.22 \mathrm{c}$ & $1.39 \mathrm{~b}$ & $0.42 \mathrm{~b}$ & $1.74 \mathrm{~b}$ \\
Calcium & $69.42 \mathrm{~d}$ & $9.59 \mathrm{c}$ & $1.31 \mathrm{~b}$ & $0.40 \mathrm{~b}$ & $1.55 \mathrm{c}$ \\
50\% Irrigation + Calcium & $81.49 \mathrm{~b}$ & $11.35 \mathrm{~b}$ & $2.27 \mathrm{a}$ & $0.64 \mathrm{a}$ & $2.68 \mathrm{a}$ \\
50\% Irrigation & $96.17 \mathrm{a}$ & $12.60 \mathrm{a}$ & $2.63 \mathrm{a}$ & $0.59 \mathrm{a}$ & $2.54 \mathrm{a}$ \\
\hline LSD $_{0.05}$ & 2.03 & 1.10 & 0.44 & 0.11 & 0.17 \\
\hline $\mathrm{p}$ & $* *$ & $* *$ & $* *$ & $* *$ & $* *$ \\
\hline
\end{tabular}

* Important at $\mathrm{p} \leq 0.05 * *$ Important at $\mathrm{p} \leq 0.01$ 
The flavonoid compound content in control was $73.87 \mathrm{mg} \mathrm{g}^{-1}$ (Table 5). The structural and electrochemical properties of flavonoids suppress lipid peroxidation and play a role in antioxidant activities that protect the membrane structure by reducing lipid oxidation (Eren et al., 2018). The reduction of lipid peroxidation is due to the removal of reactive oxygen species by flavonoids and the reduction of lipid radicals produced during lipid peroxidation. Antioxidant activity occurs depending on the number of hydroxyl groups in phenolic varieties, location and structure of the molecule (Kalefetoğlu and Ekmekçi, 2005). Flavonoids contained in phenolic compounds can scavenge reactive oxygen species. Plants have different adaptation mechanisms to reduce oxidative damage caused by drought stress and $\mathrm{Ca}$ application is one of most commonly used methods. In this study, drought stress caused an increase in total phenolic compounds and flavonoids contents.

\section{Chlorophyll contents ( $\left.\mathrm{mg} \mathrm{g}^{-1}\right)$}

The effects treatments on Chlorophyll a, Chlorophyll $b$ and Chlorophyll a b compounds were statistically significant $(\mathrm{p}<0.01)$. The lowest mean on Chlorophyll a, Chlorophyll $\mathrm{b}$ and Chlorophyll $\mathrm{a} b$ compounds (1.31, 0.40 and1.55 $\mathrm{mg} \mathrm{g}^{-1}$ ) were recorded in $\mathrm{Ca}$ application, while the highest values Chlorophyll a (50 irrigation 2.63 $\mathrm{mg} \mathrm{g}^{-1}$ ), Chlorophyll b (50\% Irrigation + Calcium $0.64 \mathrm{mg} \mathrm{g}^{-1}$ ) and Chlorophyll a b 50\% Irrigation + Calcium $2.68 \mathrm{mg} \mathrm{g}^{-1}$ ) were recorded in 50 irrigation treatment (Table 5). As the drought increases, the amount of chlorophyll increases and it is observed that the amount of chlorophyll decreases in ca applications.Water stress causes various significant changes in chlorophyll content and components due to inhibiting photosynthesis in plants, as well as damaging photosynthetic order (Sankar et al., 2008). Ashraf and Arfan (2005) determined chlorophyll content of okra plants under drought stress and reported that chlorophyll content increased with increasing stress intensity.

Water stress causes various significant changes in chlorophyll content and components due to inhibiting photosynthesis in plants, as well as damaging photosynthetic order. Ashraf and Arfan (2005) determined chlorophyll content of okra plants under drought stress and reported that chlorophyll content increased with increasing stress intensity.

\section{Conclusion}

This study revealed that foliar application of $1 \% \mathrm{CaSO}_{4}$ to tomato plants exposed to drought regulates nutrient status of plants, metabolic and transcription activities; thus, increases drought stress tolerance. The application of $1 \% \mathrm{CaSO}_{4}$ to the leaves increased plant dry matter as well as chlorophyll levels of leaves. In addition, $1 \% \mathrm{CaSO}_{4}$ application significantly increased $\mathrm{Mg}$ content of leaves and fruits. Application of $\mathrm{Ca}$ improved the tolerance to drought-related oxidative stress. Flower nose rot may occur under unstable irrigation or insufficient irrigation conditions. However, in this study, flower nose rot was not observed in the foliar application of $1 \% \mathrm{CaSO}_{4}$ under insufficient irrigation treatments. Foliar application of $1 \% \mathrm{CaSO}_{4}$ enabled tomato plants to better cope with stress by protecting fertile shoots. The growth and developments of tomato plants were relatively strong under drought stress treatments. 
Acknowledgements. This project was carried out as a Master's Thesis of OzlemBirgin in Sirnak University. We would like to thank both Sirnak University ScietificReseach Council (2020.FLTP.13.01.01) for funding the project and Cukurova University, Horticulture Department for facilities in physiology laboratory.

\section{REFERENCES}

[1] Adams, P., Ho, L. C. (1993): Effects of environment on the uptake and distribution of calcium in tomato and on the incidence of blossom-end rot. - Plant and Soil 154: 127132. https://www.jstor.org/stable/42939009.

[2] Ahmad, P., Sarwat, M., Bhat, N. A., Wani, M. R., Kazi, A. G., Tran, L. S. P. (2015): Alleviation of cadmium toxicity in Brassica juncea L. (Czern. \&Coss.) by calcium application involves various physiological and biochemical strategies. - PLoS One10:e0114571. https://doi.org/10.1371/journal.pone.0114571.

[3] Akhoundnejad, Y., Dasgan, H. Y. (2019): Effect of different irrigation levels on physiological performance of some drought tolerant melon (Cucumis melo L.) genotypes. - Applied Ecology and Environmental Research 17(4): 9997-10012. https://doi.org/10.15666/aeer/1704_999710012.

[4] Arnon, D. I. (1949): Copper Enzymes in Isolated Chloroplast: Polyphenol oxidase in (Beta Vulgaris). - Plant Physiology 14: 1-15. https://doi.org/10.1104/pp.24.1.1.

[5] Ashraf, M., Arfan, M. (2005): Gas exchange characteristics and water relations in two cultivars of Hibiscus esculentus under waterlogging. - Biologia Plantarum 49(3): 459462. https://doi.org/10.1007/s10535-005-0029-2.

[6] Bacon, M. A. (2004): Water use efficiency in plant biology. - Blackwell Publishing, Oxford, pp. 1-26.

[7] Bauer, D., Biehler, K., Fock, H., Carrayol, E., Hirel, B., Migge, A., Becker, T. W. (1997): A role for cytosolic glutamine synthetase in the remobilization of leaf nitrogen during water stress in tomato. - Physiologia Plantarum 99:241-242. https://doi.org/10.1111/j.1399-3054.1997.tb05408.x.

[8] Bergougnoux, V. (2014): The history of tomato: from domestication to biopharming. Biotechnology Advances 32: 170-89. https://doi.org/10.1016/j.biotechadv.2013.11.003.

[9] Bjelić, V., Moravčević, D. J., Beatović, D. (2005): Effect of greenhouse conditions on Zn, $\mathrm{Fe}$ and $\mathrm{Cu}$ Content in Tomato Fruits. - Journal of Agricultural Sciences50(2): 101-105. https://doi.org/doi/1450-8109/2005/1450-81090502101B.pdf.

[10] Bose, T. K., Som, M. G. (1990): Vegetable crops in India. - Naya Prakash, Calcutta-Six, India, pp. 687-691.

[11] Bray, E. A. (2004): Genes commonly regulated by water-deficit stress in Arabidopsis thaliana. - Journal of Experimental Botany 55: 2331-2341.

https://doi.org/10.1093/jxb/erh270.

[12] Daldal, N. (2018): The effect of tomato seedlings growing in calcium sulphate and calcium hydroxide added environments on blossom-end rot. - Master Thesis,ÇanakkaleOnsekiz Mart University, Institute of Science. (in Turkish).

[13] Del Amor, F., Marcelis, L. (2003): Regulation of nutrient uptake, water uptake and growth under calcium starvation and recovery. - Journal of Horticultural Scienceand Biotechnology 78: 343-349. https://doi.org/10.1080/14620316.2003.11511629.

[14] Eren, G. B., Ince, E., Gurer, O. H. (2018): In vitro antioxidant/prooxidant effects of combined use of flavonoids. - Natural Poduct Research 32(12): 1446-1450. https://doi.org/10.1080/14786419.2017.1346637. 
[15] Es-Safi, N. E., Ghidouche, S., Ducrot, P.H. (2007): Flavonoids: hemisynthesis, reactivity, characterization and free radical scavenging activity. - Molecules 12(9): 2228-2258. https://doi.org/10.3390/12092228.

[16] FAO. (2017): FAO Statistical Database. - http://www.fao.org/faostat/en/\#data/QC.

[17] Gebhardt, S. E., Thomas, R. G. (2002): Nutritive value of foods. - USDAAgricultural Research Services, Home and Garden Bulletin Number: 72, Washington, USA. 97p.

[18] Houimli, S. I. M., Jdidi, H., Boujelben, F., Mounir, D. M. (2016): Fruit yield and quality of iron-sprayed tomato (Lycopersiconesculentum Mill.) grown on high $\mathrm{pH}$ calcareous soil. - International Journal of Innovation and Scientific Research 20(2): 268-271.

[19] Kabay, T., Şensoy, S. (2016): Enzyme, chlorophyll and ion exchange caused by drought stress in some bean genotypes. - YüzüncüY1l University, Journal of Agricultural Sciences26(3): 380-395. (in Turkish). http://dergipark.gov.tr/.../284794.

[20] Kalefetoğlu, T., Ekmekçi, Y. (2005): The effects of drought on plants and tolerance mechanisms. - Gazi University Journal of Science18(4): 723-740.

[21] Lahoz, I., Pérez-de-Castro, A., Valcárcel, M., Macua, J. I., Beltránd, J., Rosellóc, S., Cebolla-Cornejo, J. (2016): Effect of water deficit on the agronomical performance and quality of processing tomato. - Scientia Horticulture 200: 55-65. https://doi.org/10.1016/j.scienta.2015.12.051.

[22] Lee, H. (2007): Contribution of working groups I, II and III to the fourth assessment report of the intergovernmental panel on climate change Climate Change. - Synthesis report104 (Geneva, Switzerland).

[23] Lester, G. E., Jifon, J. L., Makus, D. J. (2010): Impact of potassium nutrition on postharvest fruit quality: melon (Cucumis melo L.) case study. - Plant Soil 335: 117-131. https://doi.org/10.1007/s11104-009-0227-3.

[24] Marschner, H. (1995): Mineral Nutrition of Higher Plants. - Academic Press,London.

[25] Michalak, A. (2006): Phenolic compounds and their antioxidant activity in plants growing under heavy metal stress. - Polish Journal of Environmental Studies 15(4):523-530.

[26] Mishra, K. B. R., Lannacone, A., Petrozza, A., Mishra, N., Armentano, G., La Vecchia, M., Trtilek, F. C., Nedbal, L. (2012): Engineered drought tolerance in tomato plants is reflected in chlorophy. - Plant Science 182(1): 79-86. https://doi.org/10.1016/j.plantsci.2011.03.022.

[27] Molina-Quijada, D. M. A., Medina-Juárez, L. A., González-Aguilar, G. A., RoblesSánchez, R. M., Gámez-Meza, N. (2010): Phenolic compounds and antioxidant activity of table grape (Vitis vinifera L.) skin from Northwest Mexico. - CyTA-Journal of Food 8(1): 57-63. https://doi.org/10.1080/19476330903146021.

[28] Naeem, M., Naeem, M. S., Ahmad, R., Ahmad, R. (2017): Foliar applied calcium induces drought stress tolerance in maize by manipulating osmolyte accumulation and antioxıdatıve responses. - Pakistan Journal of Botany 49(2): 427-434.

[29] Okunlola, G. O., Olatunji, O. A., Akinwale, R. O., Tariq, A., Adelusi, A. A. (2017): Physiological response of the three most cultivated pepper species (Capsicum spp.) in Africa to drought stress imposed at three stages of growth and development. - Scientia Horticulturae224: 198-205. https://doi.org/10.1016/j.scienta.2017.06.020.

[30] Poovaiah, B. W. (1993): Biochemical and molecular aspects of calcium action. - Acta Horticulture 326: 139-147. https://doi.org/10.17660/ActaHortic.1993. 326.14.

[31] Ramiérez, S. L. F., Diaz, S. F. R., Muro, E. J. (2012): Relation between soilless tomato quality and potassium concentration in nutritive solution. - Acta Horticulture 947: 215222. https://doi.org/10.1016/j.scienta.2017.06.020.

[32] Sadak, A. (2018): Effect of PGPR applications on pepper seedlings under drought stress. - Master Thesis, YüzüncüY1l University, Institute of Science, Van, p. 61.

[33] Sankar, B., Abdul Jaleel, C., Manivannan, P., Kishore, K. A., Somasundaram, R., Panneerselvan, R. (2008): Relative Efficacy of Water Use in Five Varieties of Abelmoschus esculentus (L.) Moench. Under Water Limited Conditions. - Colloids SurfacesBio interfaces62: 125-129. htps://doi.org/10.1016/j.colsurfb.2007.09.025. 
[34] Sarwat, M., Ahmad, P., Nabi, G., Hu, X. (2013): $\mathrm{Ca}^{2+}$ signals: the versatile decoders of environmental cues. - Critical Reviews in Biotechnololgy 33: 97-109. https://doi.org/10.3109/07388551.2012.672398.

[35] Shabbir, R., Ahsraf, M., Waraich, E., Ahmad, R. (2015): Combined effects of drought stress and NPK foliar spray on growth, physiological processes and nutrient uptake in wheat. - Pakistan Journal of Botany 47: 1207-1216.

[36] Singleton, V. L., Rossi, J. A. (1965): Colorimetry of total phenolics with phosphomolybdic- phosphotungstic acid reagents. - American Journal of Enology and Viticulture 16: 144-158.

[37] Starck, Z., Siwiec, A., Chotuj, D. (1995): Distribution of calcium in tomato plants in response to heat stress and plant growth regulators. - Plant and Soil 167: 143-148.

[38] Tanveer, K., Gilani, S., Hussain, Z., Ishaq, R., Adeel, M., Ilyas, N. (2020): Effect of salt stress on tomato plant and the role of calcium. - Journal of Plant Nutrition 43(1): 28-35. https://doi.org/10.1080/01904167.2019.1659324.

[39] Trenberth, K. E., Dai, A., Van Der Schrier, G., Jones, P. D., Barichivich, J., Briffa, K. R., Sheffield, J.(2014): Global warming and changes in drought. - Nature Climate Change 4:17-22.https://doi.org/10.1038/nclimate2067.

[40] Tuna, A. L., Kaya, C., Ashraf, M., Altunlu, H., Yokas, I., Yagmur, B.(2007): The effects of calcium sulphate on growth, membrane stability and nutrient uptake of tomato plants grown under salt stress. - Environmental and Experimental Botany 59:173178.https://doi.org/10.1016/j.envexpbot.2005.12.007.

[41] Wahocho, N. A., Maitlo, A. A., Baloch, Q. B., Kaleri, A. A., Rajput, L. B., Talpur, N. A., Sheikh, Z. A., Mengal, F. H., Wahocho, S. A. (2017): Effect of varying levels of nitrogen on the growth and yield of muskmelon (Cucumis melo L.). - Journal of Basic and Applied Sciences13: 448-453.

[42] Wang, Y., Frei, M. (2011): Stressed food - the impact of abiotic environmental stresses on crop quality. - Agricultural Ecosystem and Environment 141: 271-86. https://doi.org/10.1016/j.agee.2011.03.017.

[43] Zorrig, W., Shahzad, Z., Abdelly, C., Berthomieu, P. (2012): Calcium enhances cadmium tolerance and decreases cadmium accumulation in lettuce (Lactuca sativa). - African Journal of Biotechnology 11: 8441-8448. https://do.org/10.5897/AJB11.2343. 